\title{
О ПОВЫШЕНИИ КОНКУРЕНТОСПОСОБНОСТИ ТУРИСТИЧЕСКОЙ ОРГАНИЗАЦИИ В СОВРЕМЕННЫХ УСЛОВИЯХ
}

В рамках настоящего исследования рассмотрены основные направления повышения конкурентоспособности туристической организации с целью завоевания рынка услуг, повыиения эффективности деятельности компании в современньх условиях хозяйствования. Сделан вывод о том, что современная деятельность в сфере туризма долэсна опираться на отраслевые особенности. В результате, важно выделять ряд общих признаков, характерных для управления в сфере туризиа: приоритет желаний конечных потребителей при планировании туристской деятельности; новизнауникальность туристской услуги; больиое зиачение маркетинга в туристской отрасли.

Ключевые слова: туристическая организачия, конкурентоспособность, экономическая среда.

\section{ON IMPROVING THE COMPETITIVENESS OF TOURISM ORGANIZATIONS IN MODERN CONDITIONS}

In the framework of this study, the main directions of improving the competitiveness of the tourism organization in order to conquer the market of services, improve the efficiency of the company in modern economic conditions. It is concluded that modern activities in the field of tourism should be based on industry characteristics. As a result, it is important to highlight a number of common features characteristic of tourism management: the priority of the desires of end users in the planning of tourism activities; novelty uniqueness of tourism services; great importance of marketing in the tourism industry.

Key words: tourist organization, competitiveness, economic environment.

Bведение / Introduction. Сфера туризма является важнейшей и составной частью экономики любого государства, а в современных условиях эта деятельность имеет ключевое значение для социально-экономических преобразований, направленных на либерализацию экономического развития нашего государства.

Недооценка необ̆ходимости использования новых технологий для организации сферы туризма, приведет к утрате возможностей использования этого сектора в укреплении экономики нашей страны [4]. В связи с этим, от всех субъектов рынка требуется активный поиск путей и методов повышения конкурентоспособности, производимых и потребляемых услуг в целях получения максимальной приб̆ыли [1]. Поэтому туристическому предприятию в результате проведения управленческого анализа и анализа деятельности конкурентов необходимо определить свои конкурентные преимущества, сформировать эффективную маркетинговую стратегию [3].

Несмотря на достаточно большое количество исследований проведенных по данной проблеме вопросы формирования финансово-экономической и сбытовой стратегии каждого предприятия, повышение конкурентоспособности для закрепления его позиций на рынке в целях получения максимальной прибыли в современных условиях экономического развития требуют совершенствования [2].

Особенно остро стоит вопрос по разработке и обоснованию предложений по повышению конкурентоспособности туристического бизнеса и ориентации его на клиента.

Результаты и обсуждение / Results and discussion. С этой целью нами была выбрана типовая для г. Ставрополя туристическая организация, проанализированы социальные, технические, экономические, политические компоненты её макроокружения, а также какое влияние, они оказывают на туристическую организацию ООО ТА «Шелковый путь» (таблица 1). 
STЕР-анализ ООО ТА «Шелковый путь»

\begin{tabular}{|c|c|c|c|c|c|c|}
\hline Факторы & $\begin{array}{c}\text { Знак } \\
\text { влияния }\end{array}$ & $\begin{array}{l}\text { Качественная } \\
\text { оценка }\end{array}$ & $\begin{array}{c}\text { Бальная } \\
\text { оценка, bi }\end{array}$ & Bec,wj & $\begin{array}{c}\text { Важность, } \\
\text { bi*wj }\end{array}$ & Критический синтез \\
\hline \multicolumn{7}{|l|}{ 1.СОЦИАЛЬНЫЕ } \\
\hline $\begin{array}{l}\text { 1. Повышение жизненного уров- } \\
\text { ня населения }\end{array}$ & + & СУЩЕСТВЕННОЕ & 5 & 0,05 & $+0,25$ & $\begin{array}{l}\text { Увеличить вложение в разные способы продвижения } \\
\text { услуг фирмы дпя поднятия интереса к туризму, актив- } \\
\text { ному отдыху }\end{array}$ \\
\hline 2. Высокий уровень образования & + & СУЩЕСТВЕННОЕ & 5 & 0,03 & $+0,15$ & $\begin{array}{l}\text { Обеспечение грамотно-спланированных услуг, ми- } \\
\text { нимизация ошибок, разработка индивидуальных и } \\
\text { vip-услуг }\end{array}$ \\
\hline $\begin{array}{l}\text { 3. Обострение межнациональных } \\
\text { конфликтов }\end{array}$ & - & СУЩЕСТВЕННОЕ & 5 & 0,05 & $-0,25$ & $\begin{array}{l}\text { Выяснить причины обострения конфликтов, возмож- } \\
\text { ность угроз для туристических маршрутов, попытать- } \\
\text { ся найти компромиссные решения }\end{array}$ \\
\hline $\begin{array}{l}\text { 4. Воспитание общественных } \\
\text { ценностей и морали }\end{array}$ & + & СЛАБОЕ & 3 & 0,04 & $+0,12$ & $\begin{array}{l}\text { Поддержание культурных норм населения, развитие } \\
\text { интереса к различным странам }\end{array}$ \\
\hline $\begin{array}{l}\text { 5. Увеличение открытости, } \\
\text { интереса, восприимчивости к } \\
\text { культурам других стран }\end{array}$ & + & ЗНАЧИТЕЛЬНОЕ & 7 & 0,05 & $+0,35$ & $\begin{array}{l}\text { Организация выставок и недель, посвященных } \\
\text { странам, с проведением кратких лекций, экскурсов в } \\
\text { историческое прошлое }\end{array}$ \\
\hline $\begin{array}{l}\text { 6. Повыптаюпийся уровень } \\
\text { мобильности населения в другие } \\
\text { страны/города РФ с целью обуче- } \\
\text { ния/отдыха }\end{array}$ & + & ЗНАЧИТЕЛЬНОЕ & 7 & 0,06 & $+0,42$ & $\begin{array}{l}\text { Вложить средства в рекламу и другие способы продви- } \\
\text { жения услуг, разработка индивидуальных маршрутов } \\
\text { и возможностей обучения/работы в других городах и } \\
\text { странах }\end{array}$ \\
\hline \multicolumn{7}{|l|}{ 2.ТЕХНОЛОГИЧЕСКИЕ } \\
\hline $\begin{array}{l}\text { 1. Существенный прогресс в } \\
\text { глобальных информационных } \\
\text { технологиях }\end{array}$ & + & СУЩЕСТВЕННОЕ & 5 & 0,03 & $+0,15$ & $\begin{array}{l}\text { Отслеживание поступления новинок на рынок, опре- } \\
\text { деление важности приобретения данньх средств }\end{array}$ \\
\hline $\begin{array}{l}\text { 2. Улучшение уровня техниче- } \\
\text { ского развития, транспортного } \\
\text { сообщения в регионе }\end{array}$ & + & СУЩЕСТВЕННОЕ & 5 & 0,02 & $+0,1$ & $\begin{array}{l}\text { Использование более быстрых средств транспортного } \\
\text { сообщения, для ускорения операций }\end{array}$ \\
\hline $\begin{array}{l}\text { 3. Возможность автоматизации } \\
\text { всех банковских переводов и } \\
\text { документооборота }\end{array}$ & + & СУЩЕСТВЕННОЕ & 5 & 0,05 & $+0,25$ & $\begin{array}{l}\text { Изучение таких возможностей и активное включение в } \\
\text { данньй процесс дпя ускорения работы }\end{array}$ \\
\hline $\begin{array}{l}\text { 4. Подготовка специалистов в } \\
\text { учебньх заведениях с использо- } \\
\text { ванием новейшихх информацион- } \\
\text { ных разработок }\end{array}$ & + & СЛАБОЕ & 3 & 0,03 & $+0,09$ & $\begin{array}{l}\text { Повышение квалификации персонала с помощњю } \\
\text { курсов и тренингов }\end{array}$ \\
\hline $\begin{array}{l}\text { 5. Увеличение вложений государ- } \\
\text { ства в НИОКР }\end{array}$ & + & СЛАБОЕ & 3 & 0,03 & $+0,09$ & $\begin{array}{l}\text { Выявить наиболее подходяпие направления НТП и } \\
\text { отслеживать изменения в этих направлениях }\end{array}$ \\
\hline
\end{tabular}




\begin{tabular}{|c|c|c|c|c|c|c|}
\hline Факторы & $\begin{array}{c}\text { Знак } \\
\text { влияния }\end{array}$ & $\begin{array}{l}\text { Качественная } \\
\text { оценка }\end{array}$ & $\begin{array}{c}\text { Бальная } \\
\text { оценка, bi }\end{array}$ & Bec,wj & $\begin{array}{c}\text { Важность, } \\
\mathbf{b i *}{ }^{*} \mathbf{j}\end{array}$ & Критический синтез \\
\hline \multicolumn{7}{|l|}{ З.ПОЛИТИЧЕСКИЕ } \\
\hline $\begin{array}{l}\text { 1. Ухудшение международной } \\
\text { обстановки/отношений }\end{array}$ & - & ЗНАЧИТЕЛЬНОЕ & 7 & 0,07 & $-0,49$ & $\begin{array}{l}\text { Проанализировать причины данного явления, по- } \\
\text { пытаться найти компромиссные решения, включая } \\
\text { пропаганду отдыха на территориях удаленшьх от зон } \\
\text { конфликтов }\end{array}$ \\
\hline $\begin{array}{l}\text { 2. Политические конфликты в } \\
\text { странах с туристическими воз- } \\
\text { можностями }\end{array}$ & - & ЗНАЧИТЕЛЬНОЕ & 7 & 0,07 & $-0,49$ & $\begin{array}{l}\text { Выявить проблемы, возникагщие на данных терри- } \\
\text { ториях, проследить, насколько сильн они оказывают } \\
\text { влияния на территории туристического отдыха, сокра- } \\
\text { щение продажи путевок в данные страны на некоторое } \\
\text { время, отслеживать политическую ситуацию. }\end{array}$ \\
\hline $\begin{array}{l}\text { 3. Негативные настроения адми- } \\
\text { нистрации и высоко-поставлен- } \\
\text { ных лиц, касаемо сферы зарубеж- } \\
\text { ного туризма }\end{array}$ & - & СУЩЕСТВЕННОЕ & 5 & 0,05 & $-0,25$ & $\begin{array}{l}\text { Выяснить причины такого отношения, чьи интересы } \\
\text { задеты, поиск компромиссных решений, заключение } \\
\text { договоров с новыми туроператорами, специализи- } \\
\text { руюшихся на отечественном туризме, отслеживание } \\
\text { изменений }\end{array}$ \\
\hline $\begin{array}{l}\text { 4. Увеличение эффективности } \\
\text { коммуникаций между посоль- } \\
\text { ствами стран, паспортно-визовы- } \\
\text { ми службами, туроператорами }\end{array}$ & + & СУЩЕСТВЕННОЕ & 5 & 0,04 & $+0,2$ & $\begin{array}{l}\text { Установление стабильных отношений с данными } \\
\text { структурами }\end{array}$ \\
\hline $\begin{array}{l}\text { 5. Повьпшение симпатий населе- } \\
\text { ния к курортам РФ }\end{array}$ & + & СЛАБОЕ & 3 & 0,06 & $+0,18$ & $\begin{array}{l}\text { Заключение контрактов/договоров с туроператорами, } \\
\text { специализирующихся на данњых направлениях }\end{array}$ \\
\hline $\begin{array}{l}\text { 6. Регулирование занятости насе- } \\
\text { ления государством }\end{array}$ & + & СЈАБОЕ & 3 & 0,05 & $+0,15$ & $\begin{array}{l}\text { Вложение денежньх средств в различные способы } \\
\text { продвижения услуг, акцент на положительном влиянии } \\
\text { даншьх предложений }\end{array}$ \\
\hline \multicolumn{7}{|l|}{ 4.ЭКОНОМИЧЕСКИЕ } \\
\hline $\begin{array}{l}\text { 1. Увеличение вложений инве- } \\
\text { стиций государства в развитие } \\
\text { Российского туризма }\end{array}$ & + & СУЩЕСТВЕННОЕ & 5 & 0,05 & $+0,25$ & $\begin{array}{l}\text { Убеждение клиентов в достойных конкурентных преи- } \\
\text { муществах Российских курортов }\end{array}$ \\
\hline $\begin{array}{l}\text { 2. Повьшение покупательской } \\
\text { способности населения }\end{array}$ & + & СУЩЕСТВЕННОЕ & 5 & 0,03 & $+0,15$ & $\begin{array}{l}\text { Вложение средств в рекламу и другие способы } \\
\text { продвижения услуг, создание более гибких условий } \\
\text { продаж для молодежи и других групп населения }\end{array}$ \\
\hline $\begin{array}{l}\text { 3. Стабилизация уровня инфля- } \\
\text { ции в стране }\end{array}$ & + & СЛАБОЕ & 3 & 0,04 & $+0,12$ & Внимательное отслеживание изменений на рынке \\
\hline $\begin{array}{l}\text { 4. Увеличение \% ставки и курса } \\
\text { наццональной валюты }\end{array}$ & + & СУЩЕСТВЕННОЕ & 5 & 0,03 & $+0,15$ & $\begin{array}{l}\text { Внимательно отслеживать информацию о валютных } \\
\text { рьшках }\end{array}$ \\
\hline $\begin{array}{l}\text { 5. Улучшение пространственной } \\
\text { организации между регионами }\end{array}$ & + & СУЩЕСТВЕННОЕ & 5 & 0,04 & $+0,2$ & $\begin{array}{l}\text { Налаживание более стабильных связей с туроперато- } \\
\text { рами из других городов }\end{array}$ \\
\hline $\begin{array}{l}\text { 6. Контроль над ценами и зара- } \\
\text { ботными платами }\end{array}$ & + & ЗНАЧНТЕЛЬНОЕ & 7 & 0,03 & $+0,21$ & Использование различных средств продвижения услуг \\
\hline & & & & 1 & 2,1 & \\
\hline
\end{tabular}


Далее на основе полученных данных нами был построен профиль внешней среды организации ООО ТА «Шелковый путь» (рис.1).

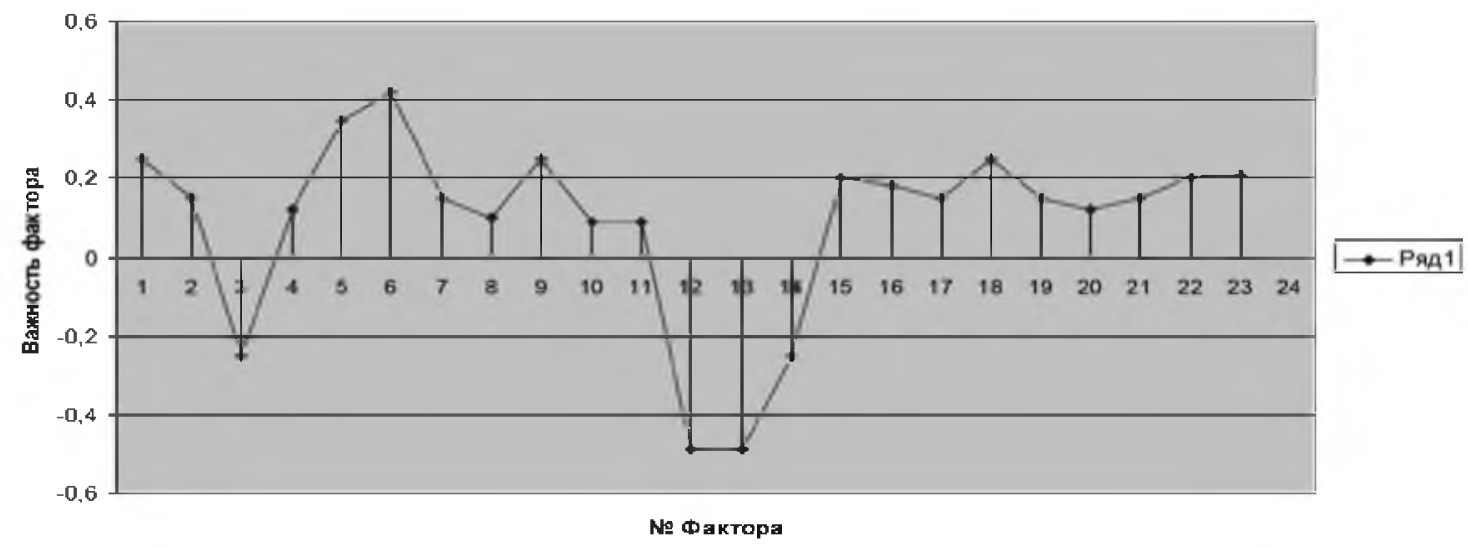

Рис. 1. Профиль внешней среды ООО ТА «Шелковый путь»

Как видно из представленных материалов, наиболее сильное отрицательное влияние на деятельность туристической организации может оказать обострение межнациональных конфликтов, т. к. это приведет к ухудшению обстановки в стране, возможны угрозы туристическим маршрутам, а следовательно потеря части дохода. Кроме того, больший урон могут оказать политические факторы, именно в их силах затруднить выезд граждан за рубеж, негативно настроить население. Социальные факторы также важно учитывать при составлении прогнозов продаж.

Появление и распространение кабельного телевидения, увеличение каналов о природе, исследованиях, истории других стран способствует пробуждению заинтересованности людей в необычных турах, а повышение уровня образования основной части населения (количество людей с высшим образованием с каждым годом увеличивается) ведет к стабилизации дохода, а, следовательно, к реальным возможностям посетить экзотические страны. Именно повышающийся уровень мобильности, рост открытости и восприимчивости населения оказывают наиболее благоприятный эффект для деятельности туристической организации.

Далее нами был выполнен анализ отраслевой конкуренции туристического агентства. Для этого воспользуемся моделью 5 сил конкуренции М. Портера. Рассмотрим каждую модель конкурентных сил подробно. Оценки были даны семью экспертами. Каждый из них является руководителем одной из конкурирующих фирм. Оценки проставлялись по пятибалльной шкале: 1 балл означает минимальное давление/минимальное значение показателя, 5 баллов - серьёзное значение фактора, уделяется особое внимание.

1. Соперничество среди конкурирующих продавцов (таблица 2).

Таблица 2

Оценка конкурентоспособности организации ТА «Шелковый путь» (соперничество существующих в отрасли компаний)

\begin{tabular}{|l|c|c|l|}
\hline \multicolumn{1}{|c|}{ Факторы конкуренции } & $\begin{array}{c}\text { Вес } \\
\text { фактора }\end{array}$ & $\begin{array}{c}\text { Средняя } \\
\text { оценка } \\
\text { фактора }\end{array}$ & Краткий комментарий \\
\hline $\begin{array}{l}\text { 1.Привлекательность рынка для уже } \\
\text { работающих конкурентов }\end{array}$ & 0,3 & 5 & Рынок привлекателен \\
\hline $\begin{array}{l}\text { 2. Степень насыщенности рынка } \\
\text { (число крупных турфирм города, } \\
\text { конкурирующих на рынке) }\end{array}$ & 0,2 & 4,5 & $\begin{array}{l}\text { Рынок в настоящее время недоста- } \\
\text { точно насыщен }\end{array}$ \\
\hline
\end{tabular}




\begin{tabular}{|l|c|c|l|}
\hline \multicolumn{1}{|c|}{ Факторы конкуренции } & $\begin{array}{c}\text { Вес } \\
\text { фактора }\end{array}$ & $\begin{array}{c}\text { Средняя } \\
\text { оценка } \\
\text { фактора }\end{array}$ & \multicolumn{1}{|c|}{ Краткий комментарий } \\
\hline $\begin{array}{l}\text { 3. Разнообразие услуг, предлагаемых } \\
\text { конкурентами рынку }\end{array}$ & 0,2 & 4 & $\begin{array}{l}\text { Большое разнообразия услуг, ока- } \\
\text { зываемых турфирмами }\end{array}$ \\
\hline $\begin{array}{l}\text { 5. Барьеры ухода с рынка (ликвид- } \\
\text { ность основных фондов и стоимость } \\
\text { затрат на ликвидацию бизнеса) }\end{array}$ & 0,15 & 3 & $\begin{array}{l}\text { Барьеры для ухода с рынка не высо- } \\
\text { ки (основные фонды ликвидны) }\end{array}$ \\
\hline $\begin{array}{l}\text { 6. Наличие и разнообразие стратегий } \\
\text { у конкурентов }\end{array}$ & 0,15 & 3,5 & $\begin{array}{l}\text { Мало кто из турфирм имеют стра- } \\
\text { тегию }\end{array}$ \\
\hline $\begin{array}{l}\text { Средневзвешенная оценка уровня } \\
\text { внутриотраслевой конкуренции }\end{array}$ & $\begin{array}{l}\text { В целом уровень внутриотраслевой } \\
\text { конкуренции в настоящее время } \\
\text { невысок - из-за низкой степени } \\
\text { насыщенности рынка }\end{array}$ \\
\hline
\end{tabular}

Туристическую деятельность в районе расположения туристической организации «Шелковый путь» также осуществляют туристические агентства ТА «Чемодан», ТТА «Сафари», ТА «Зима-Лето» и др.

Средневзвешенная оценка уровня внутриотраслевой конкуренции $0,84(<1)$, но в данном случае это означает, что конкуренты не оказывают сильного давления на фирму, не угрожают её деятельности, но влияние существует и стоит сохранять бдительность.

2. Конкурентная сила фактора угрозы появления новых конкурентов зависит от сложности барьеров входа (таблица 3 ).

Таблица 3

Оценка конкурентоспособности туристической организации ТА «Шелковый путь» (угроза появления новых конкурентов в отрасли)

\begin{tabular}{|c|c|c|c|}
\hline Факторы конкуренции & $\begin{array}{c}\text { Вес } \\
\text { фактора }\end{array}$ & $\begin{array}{c}\text { Средняя } \\
\text { оценка } \\
\text { фактора }\end{array}$ & Краткий комментарий \\
\hline $\begin{array}{l}\text { 1. Барьеры выхода на рынок (потреб- } \\
\text { ность в инвестициях, знание рынка, } \\
\text { наличие опыта и знания технологий, } \\
\text { наличие репутации, лицензии) }\end{array}$ & 0,6 & 3 & $\begin{array}{l}\text { Барьеры выхода на рынок для } \\
\text { потенциальных участников рынка } \\
\text { высоки лишь по некоторым пере- } \\
\text { численным позициям. }\end{array}$ \\
\hline $\begin{array}{l}\text { 2. Сила сопротивления работающих } \\
\text { на рынке турфирм }\end{array}$ & 0,2 & 2 & $\begin{array}{l}\text { Сила противодействия вторжению } \\
\text { потенциальных конкурентов со } \\
\text { стороны работающих на рынке тур- } \\
\text { фирм в данный момент невысока }\end{array}$ \\
\hline $\begin{array}{l}\text { 3. Важность и легкость доступа к } \\
\text { поставщикам }\end{array}$ & 0,2 & 2 & $\begin{array}{l}\text { В настоящее время потенциальные } \\
\text { конкуренты при налаженных связях } \\
\text { с высокопоставленными органами } \\
\text { могут добиться хороших результа- } \\
\text { тов }\end{array}$ \\
\hline $\begin{array}{l}\text { Средневзвешенная оценка уровня } \\
\text { давления со стороны потенциальных } \\
\text { конкурентов }\end{array}$ & & 0,87 & $\begin{array}{l}\text { Давление со стороны потенциаль- } \\
\text { ных участников рынка не ощутимо, } \\
\text { т.к. существуют определенные } \\
\text { барьеры входа }\end{array}$ \\
\hline
\end{tabular}


На наш взгляд, существует 3 основных источника барьеров:

- приверженность клиентов;

- преимущества по издержкам;

Все это создает трудности для предприятий, начинающих деятельность в данной сфере. Данная угроза всегда представляется очень вероятной. Потенциальными конкурентами для организации могут стать туристические агентства, которые способны преодолеть входной барьер.

Средневзвешенная оценка 0,87 показывает, что существуют значительные барьеры входа на рынок новых конкурентов. Для них будут преграды, прежде всего финансового характера и наличие стабильных связей у уже работающих фирм.

3. Конкуренция со стороны услуг, представленная в таблице 4, являющихся заменителями конкурентоспособных туристических агентств, не составляет серьезную конкурентную угрозу, ограничивающую цены ООО ТА «Шелковый путь» и ее прибыльность.

Таблица 4

\section{Оценка конкурентоспособности}

(конкуренция со стороны услуг, являющихся заменителями конкурентоспособных)

\begin{tabular}{|c|c|c|c|}
\hline Факторы конкуренции & $\begin{array}{c}\text { Вес } \\
\text { фактора }\end{array}$ & $\begin{array}{c}\text { Средняя } \\
\text { оценка } \\
\text { фактора }\end{array}$ & Краткий комментарий \\
\hline $\begin{array}{l}\text { 1. Возможность потребителейперехо- } \\
\text { дить на другие формы приобретения } \\
\text { услуг }\end{array}$ & 0,3 & 2 & $\begin{array}{l}\text { В настоящее время не представляет } \\
\text { серьезной угрозы, т.к. это предпо- } \\
\text { лагает своеобразные знания в об- } \\
\text { ласти компьютерной техники, сети } \\
\text { интернет и банковской структуры, } \\
\text { но немногие хотят с этим иметь } \\
\text { дело }\end{array}$ \\
\hline 2. Денежная выгода для клиентов & 0,5 & 3 & $\begin{array}{l}\text { Высокая степень ответственности } \\
\text { и новизна являются для покупате- } \\
\text { лей серьезным аргументом против } \\
\text { перехода }\end{array}$ \\
\hline $\begin{array}{l}\text { 3. Интерес и возможность клиентов } \\
\text { бронировать и оплачивать путевки } \\
\text { без посредников (турфирм) напря- } \\
\text { мую у туроператоров }\end{array}$ & 0,2 & 2,1 & $\begin{array}{l}\text { Готовность к новаторству наблю- } \\
\text { дается у малой части населения, в } \\
\text { основном у молодежи, но они не } \\
\text { выступают большинством из всех } \\
\text { клиентов }\end{array}$ \\
\hline $\begin{array}{l}\text { Средневзвешенная оценка уровня } \\
\text { конкуренции со стороны услуг, явля- } \\
\text { ющихся заменителями конкуренто- } \\
\text { способных }\end{array}$ & & 0,84 & $\begin{array}{l}\text { Давление со стороны альтернатив- } \\
\text { ных форм приобретения продуктов } \\
\text { не ощутимо }\end{array}$ \\
\hline
\end{tabular}

В первую очередь, это может быть предоставление турагентами возможности самостоятельного бронирования туров физическими лицами через интернет напрямую.

Как показывает средневзвешенная оценка, возможность появления данной альтернативы возможна для клиентов с новаторскими идеями и способностью к рискам. В основном это люди до 28 лет, или более, но не в браке, без семьи, т.е. степень ответственности у которых минимальна, риск для которых не страшен. Однако они составляют всего $10-25 \%$ от числа опрошенных клиентов 
4. Экономические возможности и торговые способности поставщиков (таблица 5).

Оценка конкурентоспособности организации ТА «Шелковый путь» (экономические возможности и торговые способности поставщиков)

\begin{tabular}{|l|c|c|l|}
\hline \multicolumn{1}{|c|}{ Факторы конкуренции } & $\begin{array}{c}\text { Вес } \\
\text { фактора }\end{array}$ & $\begin{array}{c}\text { Средняя } \\
\text { оценка } \\
\text { фактора }\end{array}$ & \multicolumn{1}{|c|}{ Краткий комментарий } \\
\hline $\begin{array}{l}\text { 1. Концентрация и организованность } \\
\text { поставщиков }\end{array}$ & 0,3 & 2 & $\begin{array}{l}\text { Концентрация и организованность } \\
\text { поставщиков ниже, чем у компа- } \\
\text { ний, что не позволяет им в данное } \\
\text { время оказывать ощутимое давле- } \\
\text { ние }\end{array}$ \\
\hline $\begin{array}{l}\text { 2. Производственные и экономиче- } \\
\text { ские возможности поставщиков дик- } \\
\text { товать рынку цены, качество, сроки и } \\
\text { условия поставок }\end{array}$ & 0,3 & 1 & $\begin{array}{l}\text { Поставщики не обладают возмож- } \\
\text { ностями диктовать предприятиям } \\
\text { свои условия поставок. }\end{array}$ \\
\hline $\begin{array}{l}\text { 3. Значимость для поставщиков обь- } \\
\text { емов закупок }\end{array}$ & 0,4 & $\begin{array}{l}\text { Поставщики предоставляпот скидки } \\
\text { постоянным клиентам, заинтересо- } \\
\text { ваны в дальнейшем сотрудничестве }\end{array}$ \\
\hline $\begin{array}{l}\text { Средневзвешенная оценка уровня } \\
\text { давления (рыночной силы) со сторо- } \\
\text { ны поставщиков }\end{array}$ & $\begin{array}{l}\text { В целом давление поставщиков } \\
\text { на рынокв настоящее время не } \\
\text { ощутимо }\end{array}$ \\
\hline
\end{tabular}

Влияние несильное, средневзвешенная оценка 0,7 менее единицы, т.е. поставщики не имеют возможности контролировать рынок.

5. Способность покупателей диктовать свои условия (таблица 6) представляет угрозу давления потребителей на цены из-за потреб̆нстей в лучшем качестве предлагаемых услуг или сервисе (сильные покупатели). В условиях рыночной конкуренции у продавцов существует негласное правило: «Покупатель всегда прав».

Оценка конкурентоспособности ООО ТА «Шелковый путь»

Таблица 6 (способность покупателей диктовать свои условия)

\begin{tabular}{|l|c|c|l|}
\hline \multicolumn{1}{|c|}{ Факторы конкуренции } & $\begin{array}{c}\text { Вес } \\
\text { фактора }\end{array}$ & $\begin{array}{c}\text { Средняя } \\
\text { оценка } \\
\text { фактора }\end{array}$ & \multicolumn{1}{|c|}{ Краткий комментарий } \\
\hline 1. Уровень потребительского спроса & 0,25 & 4 & $\begin{array}{l}\text { Уровень покупательского спроса в } \\
\text { целом по г. Ставрополь в настоящее } \\
\text { время высок, и давление со сторо- } \\
\text { ны данного фактора проявляется } \\
\text { Значительно }\end{array}$ \\
\hline $\begin{array}{l}\text { 2. Чувствительность покупателей к } \\
\text { уровню цен }\end{array}$ & 0,2 & 5 & $\begin{array}{l}\text { Потребители очень чувствительны } \\
\text { к цене, и давление потребителей } \\
\text { за счет этого фактора проявляется } \\
\text { сильно }\end{array}$ \\
\hline $\begin{array}{l}\text { 3. Чувствительность покупателей к } \\
\text { качеству предложенных услуг, на- } \\
\text { дежности, уровню обслуживания }\end{array}$ & 0,15 & $\begin{array}{l}\text { Потребители склонны выбирать } \\
\text { фирму наиболее хорошо зареко- } \\
\text { мендовавшую себя с точки зрения } \\
\text { стабильности }\end{array}$ \\
\hline
\end{tabular}




\begin{tabular}{|l|c|c|l|}
\hline \multicolumn{1}{|c|}{ Факторы конкуренции } & $\begin{array}{c}\text { Вес } \\
\text { фактора }\end{array}$ & $\begin{array}{c}\text { Средняя } \\
\text { оценка } \\
\text { фактора }\end{array}$ & \multicolumn{1}{|c|}{ Краткий комментарий } \\
\hline $\begin{array}{l}\text { 4. Чувствительность потребителей к } \\
\text { качеству услуг и уровню обслужи- } \\
\text { вания }\end{array}$ & 0,15 & 4,7 & $\begin{array}{l}\text { Всё больше покупателей стре- } \\
\text { миться к приобретению надежного } \\
\text { отдыха с полным пакетом гарантий }\end{array}$ \\
\hline $\begin{array}{l}\text { 5. Степень информированности } \\
\text { потребителей о других турфирмах в } \\
\text { регионе }\end{array}$ & 0,25 & 4 & $\begin{array}{l}\text { Информированность потребите- } \\
\text { лей о рынкев регионе достаточно } \\
\text { высока, что позволяет говорить о } \\
\text { сильном давлении покупателей }\end{array}$ \\
\hline $\begin{array}{l}\text { Средневзвешенная оценка уровня } \\
\text { давления (рыночной силы) со сторо- } \\
\text { ны покупателей }\end{array}$ & \multicolumn{2}{|l|}{$\begin{array}{l}\text { Давление покупателей наиболее } \\
\text { ощутимо, наравне с уже действую- } \\
\text { щими конкурентами }\end{array}$} \\
\hline
\end{tabular}

Так как у фирмы наблюдается достаточное число конкурентов, а г. Ставрополь небольшой, то здесь имеет место быть борьба за клиентов. Клиент в данной ситуации имеет возможность выбирать, в какую турфирму пойти, руководствуясь своим опытом и знаниями.

Опираясь на средневзвешенную оценку, можно сделать вывод, что минимальное давление и угрозу представляет появление услуг альтернативных предлагаемым $(0,86$, скорее всего, появятся, но не будут пользоваться спросом) и поставщики $(0,7)$.

У новых конкурентов также есть шансы оказать влияние, но из-за серьезных барьеров входа в отрасль и опытности, репутации уже существующих фирм, у них первоначально могут возникать проблемы. Серьезное же давление и угрозы ощущаются со стороны конкурентов в отрасли $(0,84)$ и покупателей $(0,885)$.

Для наглядности построим график, отражающий результирующее взаимодействие пяти конкурентных сил на рынке туриндустрии г. Ставрополь, и прогноз его изменения на ближайшие 2-4 года. Интегральный показатель 4,12 (рис. 2).

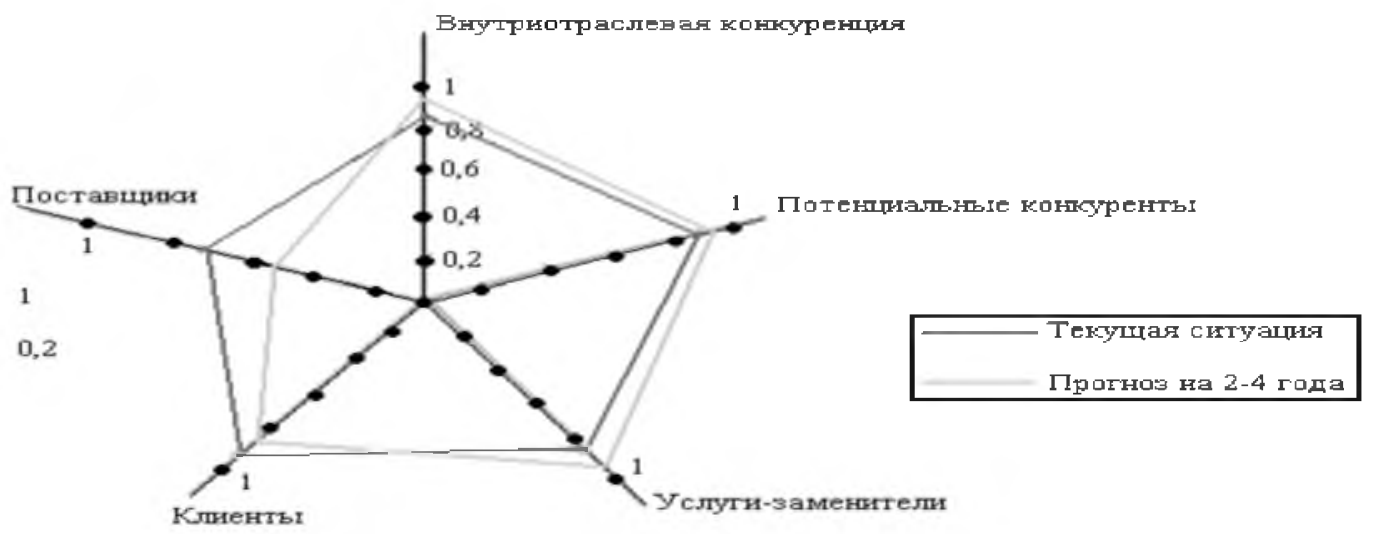

Рис. 2. Результирующее взаимодействие пяти конкурентных сил и прогноз его изменения

Ориентируясь на информацию надежных источников, можно сделать прогноз влияния на будущее всех пяти конкурентных сил. Так ожидается, что наибольшее влияние смогут оказывать услуги-заменители и клиенты.

Для того, чтобы оценить какие конкурентные позиции удерживает организации ТА «Шелковый путь» и где есть конкурентные преимущества построим профиль непосредственного окружения фирмы. С помощью этого метода можно также оценить, как и какими способами, другие организации участвуют в конкурентной борьбе. 
Исследование проводилось нами экспертным путем по пятибалльной шкале. Экспертами были выбраны люди, занимающие руководящие должности в конкурирующих компаниях. Было задействовано семь человек, ответ каждого заносился в таблицу (таблица 7).

Таблича 7

\section{Оценки экспертов по показателям конкурентоспособности фирм на рынке туристических услуг г. Ставрополя}

\begin{tabular}{|c|c|c|c|c|c|c|c|c|c|c|c|c|c|c|c|c|c|c|c|c|c|c|c|c|c|c|c|c|}
\hline \multirow{3}{*}{$\begin{array}{l}\text { Параметры } \\
\text { рганизация } \\
\end{array}$} & \multicolumn{28}{|c|}{ Эксперты } \\
\hline & \multicolumn{4}{|c|}{1} & \multicolumn{4}{|c|}{2} & \multicolumn{4}{|c|}{3} & \multicolumn{4}{|c|}{4} & \multicolumn{4}{|c|}{5} & \multicolumn{4}{|c|}{6} & \multicolumn{4}{|c|}{7} \\
\hline & 1 & 2 & 3 & 4 & 1 & 2 & 3 & 4 & 1 & 2 & 3 & 4 & 1 & 2 & 3 & 4 & 1 & 2 & 3 & 4 & 1 & 2 & 3 & 4 & 1 & 2 & 3 & 4 \\
\hline Качество услуг & 4 & 2 & 3 & 3 & 3 & 2 & 2 & 1 & 5 & 2 & 4 & 2 & 4 & 2 & 3 & 2 & 4 & 2 & 3 & 2 & 4 & 3 & 3 & 2 & 4 & 3 & 3 & 3 \\
\hline $\begin{array}{l}\text { Средняя стон- } \\
\text { мость путевки за } \\
\text { рубеж }\end{array}$ & 3 & 4 & 3 & 4 & 3 & 3 & 3 & 5 & 3 & 3 & 2 & 4 & 4 & 3 & 2 & 5 & 3 & 3 & 4 & 5 & 4 & 2 & 4 & 3 & 2 & 3 & 4 & 2 \\
\hline $\begin{array}{l}\text { Средняя стои- } \\
\text { мость путевки в } \\
\text { РФ }\end{array}$ & 2 & 3 & 1 & 1 & 3 & 4 & 1 & 2 & 2 & 2 & 2 & 3 & 1 & 4 & 2 & 4 & 2 & 2 & 3 & 4 & 3 & 4 & 2 & 4 & 2 & 2 & 4 & 3 \\
\hline $\begin{array}{l}\text { Ассортимент } \\
\text { предлагаемых } \\
\text { услуг/количество } \\
\text { туроператоров }\end{array}$ & 5 & 2 & 3 & 3 & 5 & 2 & 3 & 2 & 5 & 3 & 4 & 1 & 5 & 1 & 2 & 2 & 5 & 3 & 3 & 2 & 5 & 1 & 3 & 2 & 5 & 3 & 3 & 2 \\
\hline $\begin{array}{l}\text { Количество реа- } \\
\text { лизуемых услуг }\end{array}$ & 4 & 5 & 3 & 2 & 4 & 2 & 3 & 3 & 3 & 2 & 3 & 2 & 5 & 3 & 4 & 1 & 5 & 2 & 3 & 2 & 4 & 3 & 2 & 4 & 5 & 4 & 3 & 2 \\
\hline $\begin{array}{l}\text { Квалиф } \\
\text { персон }\end{array}$ & 3 & 3 & 3 & 3 & 3 & 3 & 2 & 2 & 2 & 2 & 4 & 2 & 4 & 2 & 3 & 2 & 4 & 2 & 3 & 3 & 3 & 1 & 4 & 1 & 3 & 2 & 3 & 1 \\
\hline $\begin{array}{l}\text { Качество систе- } \\
\text { мы отбора/найма } \\
\text { персонала }\end{array}$ & 2 & 1 & 1 & 2 & 1 & 2 & 1 & 3 & 3 & 1 & 1 & 1 & 2 & 2 & 3 & 2 & 1 & 3 & 2 & 3 & 3 & 2 & 3 & 2 & 2 & 3 & 4 & 2 \\
\hline $\begin{array}{l}\text { Расходы на ре- } \\
\text { кламу }\end{array}$ & 2 & 1 & 2 & 2 & 2 & 3 & 2 & 3 & 2 & 2 & 4 & 3 & 2 & 2 & 4 & 5 & 3 & 4 & 3 & 2 & 2 & 2 & 4 & 3 & 2 & 1 & 4 & 3 \\
\hline $\begin{array}{l}\text { Наличие ответ- } \\
\text { ственных партне- } \\
\text { ров }\end{array}$ & 4 & 3 & 2 & 3 & 5 & 2 & 3 & 4 & 3 & 3 & 2 & 5 & 4 & 1 & 5 & 3 & 4 & 3 & 4 & 3 & 5 & 3 & 3 & 1 & 5 & 1 & 3 & 2 \\
\hline $\begin{array}{l}\text { Использование } \\
\text { логистической } \\
\text { системы }\end{array}$ & 1 & 2 & 1 & 1 & 1 & 1 & 1 & 1 & 1 & 2 & 1 & 1 & 1 & 1 & 1 & 1 & 2 & 4 & 1 & 2 & 2 & 3 & 2 & 2 & 1 & 1 & 2 & 1 \\
\hline $\begin{array}{l}\text { Обустройство } \\
\text { офиса (дизайн, } \\
\text { комфортная об- } \\
\text { становка) }\end{array}$ & 5 & 4 & 1 & 2 & 5 & 4 & 2 & 1 & 5 & 4 & 2 & 3 & 5 & 5 & 2 & 2 & 4 & 2 & 3 & 3 & 5 & 5 & 1 & 3 & 5 & 4 & 4 & 1 \\
\hline $\begin{array}{l}\text { Новизна про- } \\
\text { граммного } \\
\text { обеспечения/обо- } \\
\text { рудования }\end{array}$ & 2 & 4 & 5 & 3 & 1 & 3 & 3 & 3 & 2 & 3 & 3 & 1 & 2 & 2 & 3 & 1 & 2 & 3 & 2 & 3 & 3 & 2 & 3 & 1 & 3 & 4 & 2 & 3 \\
\hline
\end{tabular}

Компании:

$1-$ ТА Шелковый путь;

$2-T A$ «емодан»;

$3-T T A «$ «aфapu»;

4-TA «3има-Лето».

Оиенки проставлялись по пятибалльной икале. I балл означает минимальное преимуцество, 2 - слабое, 3 -среднее, 4-выше среднего, в свою очередь, 5 - сильно выраженный показатель. 
Анализ турфирмы «Шелковый путь» и конкурентов представлен с учетом коэффициента весомости методом обобщенной балльной оценки в таблице 8 .

Таблица 8

Балльная оценка (с учетом коэффициента весомости)

\begin{tabular}{|c|c|c|c|c|c|c|c|c|c|}
\hline \multirow{2}{*}{ Параметры } & \multirow{2}{*}{$\begin{array}{c}\text { Коэффициент } \\
\text { весомости }\end{array}$} & \multicolumn{2}{|c|}{$\begin{array}{c}\text { ТА } \\
\text { «Шелковый путь» }\end{array}$} & \multicolumn{2}{|c|}{ ТА «Чемодап» } & \multicolumn{2}{|c|}{ TTA «Сафари» } & \multicolumn{2}{|c|}{ ТА «Зима-Лето } \\
\hline & & балл & вес & балл & Bec & балл & Bec & балл & вec \\
\hline Качество услуг & 0,1 & 4 & 0,4 & 2 & 0,2 & 3 & 0,3 & 2 & 0,2 \\
\hline $\begin{array}{l}\text { Средняя стоимость путев- } \\
\text { ки за рубеж }\end{array}$ & 0,08 & 3 & 0,24 & 3 & 0,2 & 3 & 0,24 & 4 & 0,32 \\
\hline $\begin{array}{l}\text { Средняя стоимость путев- } \\
\text { ки в РФ }\end{array}$ & 0,08 & 2 & 0,16 & 3 & 0,2 & 2 & 0,16 & 3 & 0,24 \\
\hline $\begin{array}{l}\text { Ассортимент предлага- } \\
\text { емых услуг/количество } \\
\text { туроператоров }\end{array}$ & 0,09 & 5 & 0,45 & 2 & 0,2 & 3 & 0,27 & 2 & 0,18 \\
\hline $\begin{array}{l}\text { Количество реализуемых } \\
\text { услуг }\end{array}$ & 0,08 & 4 & 0,32 & 3 & 0,2 & 3 & 0,24 & 2 & 0,16 \\
\hline Квалификация персонала & 0,09 & 3 & 0,27 & 2 & 0,2 & 3 & 0,27 & 2 & 0,18 \\
\hline $\begin{array}{l}\text { Качество системы отбора/ } \\
\text { найма персонала }\end{array}$ & 0,07 & 2 & 0,14 & 2 & 0,1 & 2 & 0,14 & 2 & 0,14 \\
\hline Расходы на рекламу & 0,1 & 2 & 0,2 & 2 & 0.2 & 3 & 0.3 & 3 & 0.3 \\
\hline $\begin{array}{l}\text { Наличие ответственных } \\
\text { партнеров }\end{array}$ & 0,08 & 4 & 0,32 & 2 & 0,2 & 3 & 0,24 & 3 & 0,24 \\
\hline $\begin{array}{l}\text { Использование логисти- } \\
\text { ческой системы }\end{array}$ & 0,05 & 1 & 0,05 & 2 & 0,1 & 1 & 0,05 & 1 & 0,05 \\
\hline $\begin{array}{l}\text { Обустройство офиса (ди- } \\
\text { зайн, комфортная обста- } \\
\text { новка) }\end{array}$ & 0,09 & 5 & 0,45 & 4 & 0,4 & 2 & 0,18 & 2 & 0,18 \\
\hline $\begin{array}{l}\text { Новизна программного } \\
\text { обеспечения/оборудова- } \\
\text { ния }\end{array}$ & 0,09 & 2 & 0,18 & 3 & 0,3 & 3 & 0,27 & 2 & 0,18 \\
\hline Сумма & 1 & 37 & 3,2 & 30 & 2,5 & 31 & 2,7 & 28 & 2,37 \\
\hline
\end{tabular}

Из полученных, путем опроса руководящего состава, оценок параметров каждой фирмы видно, что компания не всегда находится на лидирующих позициях.

Но полученная сумма баллов ООО ТА «Шелковый путь», которая превосходит аналогичную сумму других фирм, дает возможность при правильном использовании ресурсов выйти на более высокий уровень конкуренции. Наиболее выгодные позиции компания занимает по предложенному ассортименту услуг, наличию ответственных партнеров, качеству обслуживания и обустройству офиса. Менее всего компания конкурентоспособна по таким параметрам, как продвижение товара/услуг, использованию логистической системы и новизне оборудования.

Заключение / Conclusion

1. Проведенное исследование позволяет заключить, что деятельность в сфере туризма должна опираться на особенности отрасли. В соответствии с этим можно выделить ряд общих черт, характерных для управления в сфере туризма:

- приоритет желаний конечных потребителей при планировании туристской деятельности;

- новизна/уникальность туристской услуги;

- большое значение маркетинга в туристской отрасли. 
2. Конкурентными преимуществами фирмы ООО ТА «Шелковый путь» являются:

- доступ к ответственным поставщикам по обеспечению рабочего процесса; высокий уровень сервиса;

- высококвалифицированный персонал, нацеленность на качество, быстрое реагирование и приспособление к изменениям во внешней среде; выгодное территориальное расположение в центре города, доступ к финансовым ресурсам. Однако из-за нерационального распределения ресурсов организация теряет большие возможности, такие как: завоевание новых клиентов, покупка более современного компьютерного обеспечения, ускорение работы, расширение деятельности.

3. Для увеличения доли рынка на $20 \%$, используя возможности рыночной ситуации, туристическая организация ООО ТА «Шелковый путь» важно обеспечить наращивание научно-технического потенциала организации, маркетингового потенциала, сервисного обслуживания.

\section{ЛИТЕРАТУРА И ИНТЕРНЕТ-РЕСУРСЫ}

1. Антонов, Г.Д., Иванова, О.П. Тумин, В.М. Управление конкурентоспособностью организации. М. : Инфра-М, 2012. - 304 с.

2. Братенкова, Т.М. Маркетинг в туристической индустрии : тексты лекций для студентов специальности 1-89 0202 Туризм и природопользование / Т. М. Братенкова. - Минск : БГТУ, 2014. - 127 с.

3. Попов, В.Н. Системный анализ в менеджменте : учеб. пособие / В. Н. Попов, В. С. Касьянов, И. П. Савченко; под ред. д-ра экон. наук, проф. В.Н. Попова. - М. : КНОРУС, 2016.

4. Черненко, М. В. Специфика современной организации и системы управления в сфере туристских услуг и её взаимосвязь с конкурентоспособностью // Актуальные проблемы развития общества, экономики и права: сборник научных статей молодых преподавателей и аспирантов. - М. : Московский университет им. С. Ю. Витте, 2015. С. 132-139

\section{REFERENCES AND INTERNET RESOURCES}

1. Antonov, G. D., Ivanova, O. P. Tumin, V. M. Upravlenie konkurentosposobnost'ju organizacii (Management of competitiveness of the organization). - M. : Infra-M, 2012. - $304 \mathrm{p}$.

2. Bratenkova, T.M. Marketing $\mathrm{v}$ turisticheskoj industrii (Marketing in the tourism industry) : teksty lekcij dlja studentov special'nosti 1-89 0202 «Turizm i prirodopol'zovanie» / T. M. Bratenkova. - Minsk : BGTU, 2014. $-127 \mathrm{p}$.

3. Popov, V. N. Sistemnyj analiz v menedzhmente (System analysis in management): ucheb. posobie / V.N. Popov, V. S. Kas'janov, I. P. Savchenko; pod red. d-ra jekon. nauk, prof. V. N. Popova. - M. : KNORUS, 2016.

4. Chernenko, M. V. Specifika sovremennoj organizacii i sistemy upravlenija v sfere turistskih uslug i ejo vzaimosvjaz's konkurentosposobnost'ju (The specifics of modern organization and management system in the field of tourism services and its relationship with competitiveness), Aktual'nye problemy razvitija obshhestva, jekonomiki i prava: sbornik nauchnyh statej molodyh prepodavatelej i aspirantov. - M. : Moskovskij universitet im. S.Ju. Vitte, 2015. P. 132-139

\section{СВЕДЕНИЯ ОБ АВТОРЕ}

Журавель Виталий Федорович, доктор экономических наук, доцент, профессор кафедры менеджмента Института экономики и управления ФГАОУ ВО «Северо-Кавказский федеральный университет». E-mail: zhuravelvf@yandex.ru

\section{INFORMATION ABOUT AUTHOR}

Vitaly Zhuravel, doctor of economic Sciences, associate Professor, Professor of the Department of management, Institute of Economics and management, North Caucasus Federal University. E-mail: zhuravelvf@yandex.ru 